\title{
Study of the Pattern of Brucellosis in Menoufyia Governorate
}

\author{
Atef Abo EL-Soud Ali ${ }^{1}$, Ayman Mohammed El-Lehleh ${ }^{1}$, \\ Somaia Abd El-Mohsen Shehab El-Deen ${ }^{1}$, Amira Abd El-Kader El-Hendy ${ }^{2}$, \\ EL Sayed Mahmoud Mohammed Mousa ${ }^{1}$ \\ ${ }^{I}$ Tropical Medicine Department, Faculty of Medicine, Menoufiya University ,Egypt \\ ${ }^{2}$ Clinical Pathology Department, Faculty of Medicine, Menoufiya University, Egypt
}

Corresponding Author: EL Sayed Mahmoud Mohammed Mousa

Mobile:

$+0201144938029$

E mail: Sayed_m364 @yahoo.com

Key words: Human brucellosis, ELISA IgG and IgM test for brucella, Serum samples
Background and study aim: ELISA can determine specific antibody classes against brucella, It is a sensitive, simple and rapid test, thus help to study the pattern of the brucellosis. The aim of this article is to study the pattern of the brucellosis in Menoufyia governorate.

Patients and methods: Sera from 150 individuals from confirmed brucellosis cases and 25 healthy individuals were tested for presence of $\mathrm{IgG}$ and $\mathrm{IgM}$ antibodies by ELISA assay. Culture positivity for brucellosis was used as the reference standard for diagnosis.
Results: Serum IgG and IgM for brucellosis by ELISA test had increased values in confirmed brucella cases, ELISA IgM was highly specific $(100 \%)$ in all groups and sensitive (96\%) in acute brucellosis, (100\%) in subacute brucellosis and $(64 \%)$ in chronic brucellosis. While, ELISA IgG specificity in all groups was $(80 \%)$ and the sensitivity in acute brucellosis was $(88 \%)$, in subacute and chronic brucellosis was (100\%).

Conclusion: ELISA IgG and IgM test for brucella is a simple and reliable test in the diagnosis of pattern of the brucellosis.

\section{INTRODUCTION}

Brucellosis is a worldwide zoonosis caused by the facultative intracellular members of the bacterial genus Brucella of which at least six species are now recognized; these are highly genetically homogenous and the disease is of major socio-economic importance [1].

Brucellosis is a significant health problem in Egypt and a confirmed cause of $3 \%$ of acute febrile illnesses [2].

The estimated annual incidence of brucellosis in Egypt per 100000 population was 64 and 70 in 2002 and 2003, respectively [3].

Diagnosis of the disease is challenging and is frequently delayed or missed because the clinical picture may mimic other infectious and non-infectious conditions, It is often missed because of its non-specific symptoms unless the clinician is aware of the organism and maintains a high degree of suspicion so, diagnosis can be established by laboratory methods such as, serology and blood cultures [4].

In absence of bacteriologic confirmation, a presumptive diagnosis can be made on the basis of high or rising titers of specific antibodies [5].

Therefore, accurate diagnosis of brucellosis is vital for early institution of proper therapy as untreated cases may progress to chronic stage and focal complications [6].

\section{PATIENTS AND METHODS}

This study was carried out in Menoufiya Fever Hospitals and Tropical Medicine Department, Faculty of Medicine, Menoufiya University hospitals.

The study was conducted on two groups: The patient group (group I) is one hundered and fifty patients diagnosed as having brucellosis (based on: Detection of specific antibodies at significant titers by STAT and positive 
isolation of $\mathrm{Br}$. species in blood samples). Group I was divided into the following 3 subgroups according to duration of disease: group Ia comprised eighty nine patients with acute brucellosis. Group Ib comprised forty two patients with subacute brucellosis. Group Ic comprised nineteen patients with chronic brucellosis .Group II was twenty five normal healthy individuals of matched age and sex as a control group. After having an informed consent; each patient underwent: detailed history taking: personal history, patient's complaints with stress on afternoon fever, profuse sweating and headache, present history with stress on history of contact with animals, drinking unpasteurized milk, ingestion of home made dairy products and duration of symptoms that were reported, past history of chest diseases or other diseases and family history.

Clinical examination with stress on fever, lymphadenopathy, hepatomegaly, slenomegaly, enlarged testes and tenderness of the back.

Investigations: Full routine laboratory investigations: complete urine analysis and stool analysis, complete blood count, Erythrocyte sedimentation rate (ESR) \&C-reactive protein (CRP), Liver function tests including serum total and direct bilirubin, ALT, AST and serum albumin, hepatitis viral markers were done for each case with elevated transaminases and bilirubin, Serological diagnostic techniques for brucellosis as agglutination tests was done (Rose bengal slide agglutination test, rapid slide titration test, tube agglutination test for brucellosis and mercaptoethanol agglutination test for brucellosis).

Radiological investigations (Chest radiography, radiographic study of the spine, both sacroilliac joints and peripheral joints, scrotal ultrasonography and abdominopelvic ultrasonography).

IgG and $\operatorname{IgM}$ for brucellosis was measured in serum samples of the patients and control groups using ELISA kit.

\section{Statistical analysis}

Data were collected, tabulated and statistically analyzed by computer using SPSS version 20 . The following tests; sensitivity, specificity, Significance of results ( $\mathrm{P}$ value) and Chi square test were calculated to compare the efficacy of ELISA IgG \& ELISA IgG assay with blood culture and STAT to assess the pattern of the brucellosis in Menoufyia governorate.

\section{RESULTS}

No statistical significant differences among the studied groups as regarding age and sex as shown in table (I). Patients with chronic and subacute brucellosis were significantly more frequent among residents of rural areas than patients with acute brucellosis and control subjects, while patients with acute brucellosis and control subjects were significantly more frequent among residents of urban areas than patients with chronic and subacute brucellosis as shown in table (2). Constitutional symptoms and symptoms of localization were present in various proportions in the different patients groups. Osteoarticular symptoms were significantly more frequent in the acute stage, weight loss and anxiety were significantly more frequent in the chronic stage while palpitations was significantly more frequent in the subacute stage as shown in table (3). Splenomegaly and hepatomegaly were more frequent in the acute stage than in the subacute or chronic stages as shown in table (4). Fever, pallor, jaundice and signs of localization were present in various proportions in the studied patients groups. splenomegaly, lymphadenopathy and hepatomegaly were significantly more frequent in the acute stage than in the subacute or chronic stages as shown in table (4). Positive titer $\geq 1 / 1280$ was highly significant more frequent in acute and subacute stages of brucellosis than in chronic stage and control group. Positive titer $1 / 640$ was significantly more frequent in patients groups at different stages of disease than in control group. Positive titer $1 / 320$ was significantly more frequent in subacute and chronic stages than in acute stage and control group. Positive titer $1 / 160$ was significantly more frequent in chronic stage than in acute, subacute stages and control group. Negative serology and positive titer $<1 / 160$ were significantly more frequent in control group than patients groups at different stages of disease as shown in table (5). Positive blood culture was highly significantly more frequent in acute and subacute stages than in chronic stage and control group as shown in tables (6). ELISA IgM test was positive in all patients with subacute brucellosis (100\%), most patients with acute brucellosis (95.5\%), most patients with chronic brucellosis (64\%), as shown in table (7) while, ELISA IgG was specific in all groups is $(80 \%)$ and the sensitivity in acute brucellosis was (87.6\%), in subacute and chronic brucellosis was (100\%) as shown in table (8). ELISA IgM is highly specific and sensitive 
in all groups and ELISA IgG is specific in subacute and chronic groups. blood culture is specific in all groups but with low sensitivity.
STAT is sensitive in all patients groups but with low specificity (table 9).

Table (1): Shows the age and sex distribution of the studied groups

\begin{tabular}{|c|c|c|c|c|c|c|c|c|c|c|c|c|c|}
\hline & \multicolumn{8}{|c|}{ Patients groups } & \multirow{2}{*}{\multicolumn{2}{|c|}{$\begin{array}{c}\text { Control group } \\
\text { Group II } \\
(\mathrm{N}=\mathbf{2 5})\end{array}$}} & \multirow{3}{*}{$\chi^{2}$} & \multirow{3}{*}{$\begin{array}{c}\mathbf{P} \\
\text { value }\end{array}$} \\
\hline & & \multicolumn{2}{|c|}{$\begin{array}{c}\text { Group Ia } \\
(\mathrm{N}=89)\end{array}$} & \multicolumn{2}{|c|}{$\begin{array}{c}\text { Group Ib } \\
(\mathrm{N}=42)\end{array}$} & \multicolumn{2}{|c|}{$\begin{array}{c}\text { Group Ic } \\
(\mathrm{N}=19)\end{array}$} & \multicolumn{2}{|c|}{$\begin{array}{c}\text { Total } \\
(\mathbf{N}=150)\end{array}$} & & & & \\
\hline & & No & $\%$ & No & $\%$ & No & $\%$ & No & $\%$ & No & $\%$ & & \\
\hline \multirow{3}{*}{ Age } & $\langle 15 \mathrm{y}$ & 17 & 19.1 & 5 & $\overline{11.9}$ & 1 & 5.2 & 23 & 15.3 & 5 & 20 & 0.35 & $>0.05$ \\
\hline & $15-45 y$ & 57 & 64 & 28 & 66.6 & 13 & 68.4 & 98 & 65.3 & 16 & 64 & 0.02 & $>0.05$ \\
\hline & $>45 y$ & 15 & 16.9 & 9 & 21.5 & 5 & 26.4 & 29 & 19.4 & 5 & 20 & 0.01 & $>0.05$ \\
\hline \multirow[t]{2}{*}{ Sex } & Male & 64 & 71.9 & 26 & 61.9 & 11 & 57.8 & 101 & 67.3 & 21 & 84 & \multirow{2}{*}{1.88} & \multirow{2}{*}{$>0.05$} \\
\hline & Female & 25 & 28.1 & 16 & 36.1 & 8 & 42.2 & 49 & 32.7 & 5 & 20 & & \\
\hline
\end{tabular}

$\mathrm{X} 2$ :Chi square test.

$\mathrm{P}$ value : Significance of results: Non significant difference if $\mathrm{P}>0.05$, Significant difference if $\mathrm{P}<0.05$ and Highly significant difference if $\mathrm{P}<0.01$

Table (2): Shows the residence distribution of the studied groups

\begin{tabular}{|c|c|c|c|c|c|c|c|c|c|c|c|c|}
\hline \multirow{3}{*}{ Place } & \multicolumn{8}{|c|}{ Patients groups } & \multirow{2}{*}{\multicolumn{2}{|c|}{$\begin{array}{c}\begin{array}{c}\text { Control } \\
\text { group }\end{array} \\
\text { Group II } \\
(\mathbf{N}=\mathbf{2 5})\end{array}$}} & \multirow{3}{*}{$\chi^{2}$} & \multirow{3}{*}{$\begin{array}{c}\mathbf{P} \\
\text { value }\end{array}$} \\
\hline & \multicolumn{2}{|c|}{$\begin{array}{c}\text { Group Ia } \\
(\mathrm{N}=89)\end{array}$} & \multicolumn{2}{|c|}{$\begin{array}{c}\text { Group Ib } \\
(\mathrm{N}=42)\end{array}$} & \multicolumn{2}{|c|}{$\begin{array}{c}\text { Group Ic } \\
(\mathbf{N}=19)\end{array}$} & \multicolumn{2}{|c|}{$\begin{array}{c}\text { Total } \\
(\mathbf{N}=\mathbf{1 5 0})\end{array}$} & & & & \\
\hline & No & $\%$ & $\overline{\text { No }}$ & $\%$ & $\overline{\text { No }}$ & $\%$ & No & $\%$ & $\overline{\text { No }}$ & $\%$ & & \\
\hline Rural & 67 & 75.3 & 40 & $\overline{95.2}$ & 19 & 100 & 126 & 84 & 20 & 80 & & \\
\hline Urban & 22 & 24.7 & 2 & 4.8 & 0 & $\overline{0}$ & 24 & 12 & 5 & 20 & 46.6 & $<0.01$ \\
\hline
\end{tabular}

Table (3): Clinical Symptoms of the studied patients groups

\begin{tabular}{|c|c|c|c|c|c|c|c|c|c|c|}
\hline \multirow{3}{*}{ Symptoms } & \multicolumn{8}{|c|}{ Patients groups } & \multirow{3}{*}{$\chi^{2}$} & \multirow{3}{*}{$P$ value } \\
\hline & \multicolumn{2}{|c|}{$\begin{array}{c}\text { Group Ia } \\
(\mathrm{N}=89)\end{array}$} & \multicolumn{2}{|c|}{$\begin{array}{c}\text { Group Ib } \\
(\mathrm{N}=42)\end{array}$} & \multicolumn{2}{|c|}{$\begin{array}{c}\text { Group Ic } \\
(\mathrm{N}=19)\end{array}$} & \multicolumn{2}{|c|}{$\begin{array}{c}\text { Total } \\
(\mathrm{N}=150) \\
\end{array}$} & & \\
\hline & No & $\%$ & No & $\%$ & No & $\%$ & No & $\%$ & & \\
\hline Fatigue & 89 & 100 & 33 & 78.5 & 12 & 63.1 & 134 & 89.3 & 29.3 & $<0.001$ \\
\hline Fever & 81 & 91 & 31 & 73.8 & 11 & 57.9 & 123 & 82 & 12.9 & $<0.001$ \\
\hline Chills & 85 & 95.5 & 31 & 73.8 & 13 & 68.4 & 129 & 86 & 16.7 & $<0.001$ \\
\hline Bodyaches & 78 & 87.6 & 23 & 54.7 & 8 & 42.1 & 109 & 72.7 & 25.7 & $<0.001$ \\
\hline Arthralgia & 74 & 83.1 & 20 & 47.6 & 9 & 47.4 & 103 & 68.7 & 21.3 & $<0.001$ \\
\hline Back pain & 71 & 79.8 & 20 & 47.6 & 7 & 36.8 & 98 & 65.3 & 20.8 & $<0.001$ \\
\hline Headache & 71 & 79.8 & 30 & 71.4 & 11 & 57.9 & 112 & 74.7 & 4.3 & $>0.05$ \\
\hline Appetite loss & 64 & 71.9 & 16 & 38 & 8 & 42.1 & 88 & 58.7 & 15.9 & $<0.001$ \\
\hline Palpitations & 21 & 23.5 & 21 & 50 & 3 & 15.8 & 45 & 30 & 11.5 & $<0.001$ \\
\hline Sweating & 67 & 75.2 & 20 & 47.6 & 7 & 36.8 & 94 & 62.7 & 15.5 & $<0.001$ \\
\hline Nausea/vomiting & 49 & 55 & 7 & 16.7 & 4 & 21 & 60 & 40 & 20.8 & $<0.001$ \\
\hline Abdominal pain & 46 & 51.6 & 18 & 42.9 & 5 & 26.3 & 69 & 46 & 4.3 & $>0.05$ \\
\hline Anxiety & 3 & 3.4 & 2 & 4.8 & 10 & 52.6 & 15 & 10 & 43.9 & $<0.001$ \\
\hline Weight loss & 28 & 31.5 & 23 & 54.8 & 16 & 84.2 & 67 & 44.7 & 20.0 & $<0.001$ \\
\hline Cough & 10 & 11.2 & 2 & 4.8 & 1 & 5.3 & 13 & 8.7 & 1.8 & $>0.05$ \\
\hline Scrotal pain & 3 & 3.4 & 3 & 7.1 & 1 & 5.3 & 7 & 4.7 & 0.93 & $>0.05$ \\
\hline
\end{tabular}


Table (4): Result of clinical examination of the studied groups

\begin{tabular}{|c|c|c|c|c|c|c|c|c|c|c|c|c|}
\hline \multirow{3}{*}{ Findings } & \multicolumn{8}{|c|}{ Patients groups } & \multirow{2}{*}{\multicolumn{2}{|c|}{$\begin{array}{c}\begin{array}{c}\text { Control } \\
\text { group }\end{array} \\
\text { Group II } \\
(\mathrm{N}=25)\end{array}$}} & \multirow{3}{*}{$\chi^{2}$} & \multirow{3}{*}{$\begin{array}{c}P \\
\text { value }\end{array}$} \\
\hline & \multicolumn{2}{|c|}{$\begin{array}{l}\text { Group Ia } \\
(\mathrm{N}=89)\end{array}$} & \multicolumn{2}{|c|}{$\begin{array}{c}\text { Group Ib } \\
(\mathrm{N}=42)\end{array}$} & \multicolumn{2}{|c|}{$\begin{array}{c}\begin{array}{c}\text { Group Ic } \\
(\mathrm{N}=19)\end{array} \\
\end{array}$} & \multicolumn{2}{|c|}{$\begin{array}{c}\text { Total } \\
(\mathrm{N}=150)\end{array}$} & & & & \\
\hline & $\mathrm{No}$ & $\%$ & No & $\%$ & No & $\%$ & No & $\%$ & No & $\%$ & & \\
\hline Fever & 50 & 56.1 & 7 & 16.7 & 1 & 5.2 & 58 & 38.7 & 0 & 0 & 14.4 & $<0.01$ \\
\hline Pallor & 35 & 39.3 & 10 & 23.8 & 4 & 21 & 49 & 32.7 & 0 & 0 & 11.3 & $<0.01$ \\
\hline Hepatomegaly & 7 & 7.9 & 2 & 4.8 & 0 & 0 & 9 & 6 & 1 & 4 & 0.16 & $>0.05$ \\
\hline Jaundice & 50 & 56.1 & 5 & 11.9 & 3 & 15.8 & 58 & 38.7 & 0 & 0 & 14.4 & $<0.01$ \\
\hline Lymphadenopathy* & 50 & 56.1 & 7 & 16.7 & 1 & 5.2 & 58 & 38.7 & 0 & 0 & 14.4 & $<0.01$ \\
\hline Splenomegaly & 53 & 59.5 & 10 & 23.8 & 2 & 10.5 & 65 & 43.3 & 0 & 0 & 17.2 & $<0.01$ \\
\hline Ascites & 0 & 0 & 0 & 0 & 1 & 5.2 & 1 & 0.6 & 0 & 0 & 0.17 & $>0.05$ \\
\hline Sacroiliitis & 4 & 4.5 & 2 & 4.8 & 2 & 10.5 & 8 & 5.3 & 0 & 0 & 1.4 & $>0.05$ \\
\hline Peripheral arthritis & 4 & 4.5 & 0 & 0 & 0 & 0 & 4 & 2.7 & 0 & 0 & 0.68 & $>0.05$ \\
\hline Spondylodiskitis & 0 & 0 & 2 & 4.8 & 1 & 5.2 & 3 & 2 & 0 & 0 & 0.51 & $>0.05$ \\
\hline $\begin{array}{l}\text { Signs of chest } \\
\text { infection }\end{array}$ & 4 & 4.5 & 0 & 0 & 0 & 0 & 4 & 2.7 & 0 & 0 & 0.68 & $>0.05$ \\
\hline $\begin{array}{l}\text { Signs of } \\
\text { epididymoorchitis }\end{array}$ & 4 & 4.5 & 3 & 7.1 & 1 & 4 & 8 & 5.3 & 0 & 0 & 1.4 & $>0.05$ \\
\hline
\end{tabular}

Table (5) : The titers of standard tube agglutination test of the studied groups

\begin{tabular}{|c|c|c|c|c|c|c|c|c|c|c|c|c|}
\hline \multirow{3}{*}{ Titers } & \multicolumn{8}{|c|}{ Patients groups } & \multirow{2}{*}{\multicolumn{2}{|c|}{$\begin{array}{c}\text { Control } \\
\text { group }\end{array}$}} & \multirow{3}{*}{$\chi^{2}$} & \multirow{3}{*}{$P$ value } \\
\hline & \multicolumn{2}{|c|}{$\begin{array}{c}\text { Group Ia } \\
(\mathrm{N}=89)\end{array}$} & \multicolumn{2}{|c|}{$\begin{array}{c}\text { Group Ib } \\
(\mathrm{N}=42)\end{array}$} & \multicolumn{2}{|c|}{$\begin{array}{c}\text { Group Ic } \\
(\mathrm{N}=19)\end{array}$} & \multicolumn{2}{|c|}{$\begin{array}{c}\text { Total } \\
(\mathbf{N}=150)\end{array}$} & & & & \\
\hline & $\overline{\text { No }}$ & $\%$ & No & $\%$ & $\overline{\text { No }}$ & $\%$ & $\overline{\text { No }}$ & $\%$ & $\overline{\text { No }}$ & $\%$ & & \\
\hline$\geq 1 / 1280$ & 53 & 59.5 & 13 & 31 & 1 & 5.2 & 67 & 44.7 & 0 & 0 & 18.1 & $<0.001$ \\
\hline $1 / 640$ & 18 & 20.2 & 13 & 31 & 5 & 26.3 & 36 & 24 & $\overline{0}$ & $\overline{0}$ & 7.55 & $<0.001$ \\
\hline $1 / 320$ & 7 & 7.9 & 11 & 26.1 & 9 & 47.3 & 27 & 18 & $\overline{0}$ & $\overline{0}$ & 5.3 & $<0.05$ \\
\hline $1 / 160$ & 0 & 0 & 0 & 0 & 2 & 10.6 & 2 & 1.3 & 2 & 8 & 4.3 & $<0.05$ \\
\hline$<1 / 160$ & 0 & 0 & 0 & 0 & 0 & 0 & 0 & 0 & 3 & 12 & 18.3 & $<0.001$ \\
\hline Negative & 11 & 12.4 & 5 & 11.9 & 2 & 10.6 & 18 & 12 & 20 & 80 & 58.3 & $<0.001$ \\
\hline
\end{tabular}

Table (6): The results of blood culture of the studied groups

\begin{tabular}{|c|c|c|c|c|c|c|c|c|c|c|c|c|}
\hline \multirow{3}{*}{$\begin{array}{c}\text { Blood } \\
\text { culture }\end{array}$} & \multicolumn{8}{|c|}{ Patients groups } & & $\begin{array}{l}\text { rol } \\
\text { up }\end{array}$ & \multirow{2}{*}{$\chi^{2}$} & \multirow{2}{*}{ P value } \\
\hline & \multicolumn{2}{|c|}{$\begin{array}{c}\begin{array}{c}\text { Group Ia } \\
(\mathrm{N}=89)\end{array} \\
\end{array}$} & \multicolumn{2}{|c|}{$\begin{array}{c}\text { Group Ib } \\
(\mathrm{N}=42)\end{array}$} & \multicolumn{2}{|c|}{$\begin{array}{c}\text { Group Ic } \\
(\mathrm{N}=19)\end{array}$} & \multicolumn{2}{|c|}{$\begin{array}{c}\text { Total } \\
(\mathbf{N}=150)\end{array}$} & & $\begin{array}{l}\text { p II } \\
25) \\
\end{array}$ & & \\
\hline & No & $\%$ & No & $\%$ & No & $\%$ & No & $\%$ & No & $\%$ & \multirow{3}{*}{11.0} & \multirow{3}{*}{$<0.001$} \\
\hline Positive & 32 & 36 & 15 & 36 & 1 & 5.3 & 48 & 32 & 0 & $\overline{0}$ & & \\
\hline Negative & 57 & 64 & 27 & 64 & 18 & 94.7 & 102 & 68 & 25 & 100 & & \\
\hline
\end{tabular}


Table (7): The results of ELISA IgM test of the studied groups

\begin{tabular}{|c|c|c|c|c|c|c|c|c|c|c|c|c|}
\hline \multirow{3}{*}{$\begin{array}{c}\text { ELISA } \\
\text { IgM test }\end{array}$} & \multicolumn{8}{|c|}{ Patients groups } & \multirow{2}{*}{\multicolumn{2}{|c|}{$\begin{array}{c}\begin{array}{c}\text { Control } \\
\text { group }\end{array} \\
\text { Group II } \\
(\mathbf{N}=25)\end{array}$}} & \multirow{2}{*}{$\chi^{2}$} & \multirow{2}{*}{$P$ value } \\
\hline & \multicolumn{2}{|c|}{$\begin{array}{c}\text { Group Ia } \\
(\mathrm{N}=89)\end{array}$} & \multicolumn{2}{|c|}{$\begin{array}{c}\text { Group Ib } \\
(\mathrm{N}=\mathbf{4 2})\end{array}$} & \multicolumn{2}{|c|}{$\begin{array}{c}\text { Group Ic } \\
(\mathrm{N}=19)\end{array}$} & \multicolumn{2}{|c|}{$\begin{array}{c}\begin{array}{c}\text { Total } \\
(\mathbf{N}=150)\end{array} \\
\end{array}$} & & & & \\
\hline & No & $\%$ & No & $\%$ & No & $\%$ & No & $\%$ & No & $\%$ & \multirow{3}{*}{112.6} & \multirow{3}{*}{$<0.001$} \\
\hline Positive & 85 & 95.5 & 42 & 100 & 12 & 64 & 139 & 92.7 & $\overline{0}$ & 0 & & \\
\hline Negative & 4 & 4.5 & $\overline{0}$ & 0 & 7 & 36 & 11 & 7.3 & 25 & 100 & & \\
\hline
\end{tabular}

Table (8): The results of ELISA IgG test of the studied groups

\begin{tabular}{|c|c|c|c|c|c|c|c|c|c|c|c|c|}
\hline \multirow{3}{*}{$\begin{array}{c}\text { ELISA } \\
\text { IgM test }\end{array}$} & \multicolumn{8}{|c|}{ Patients groups } & & & \multirow{2}{*}{$\chi^{2}$} & \multirow{2}{*}{$P$ value } \\
\hline & \multicolumn{2}{|c|}{$\begin{array}{c}\text { Group Ia } \\
(\mathrm{N}=89)\end{array}$} & \multicolumn{2}{|c|}{$\begin{array}{c}\text { Group Ib } \\
(\mathrm{N}=\mathbf{4 2})\end{array}$} & \multicolumn{2}{|c|}{$\begin{array}{c}\text { Group Ic } \\
(\mathrm{N}=19)\end{array}$} & \multicolumn{2}{|c|}{$\begin{array}{c}\text { Total } \\
(\mathbf{N}=150)\end{array}$} & \multicolumn{2}{|c|}{$\begin{array}{c}\text { Group II } \\
(\mathrm{N}=\mathbf{2 5})\end{array}$} & & \\
\hline & No & $\%$ & No & $\%$ & No & $\%$ & No & $\%$ & No & $\%$ & \multirow{3}{*}{77.6} & \multirow{3}{*}{$<0.001$} \\
\hline Positive & 78 & 87.6 & 42 & 100 & 19 & 100 & 139 & 92.7 & 5 & 20 & & \\
\hline Negative & 11 & 12.4 & 0 & 0 & 0 & 0 & 11 & 7.3 & 20 & 80 & & \\
\hline
\end{tabular}

Table (9): The comparison of the efficacy of ELISA IgM assay with blood culture and STAT

\begin{tabular}{|c|c|c|c|c|}
\hline & ELISA IgM & ELISA IgG & Blood culuture & STAT \\
\hline Group Ia(89) & 95.5 & 87.6 & 36 & 88 \\
\hline Sensitivity (\%) & 100 & 80 & 100 & 80 \\
\hline Specificity (\%) & 100 & 100 & 36 & 92 \\
\hline GroupIb (42) & 100 & 80 & 100 & 80 \\
\hline Sensitivity (\%) & \multicolumn{5}{|l|}{} \\
\hline Specificity (\%) & 64 & 100 & 10.5 & 92 \\
\hline Group Ic (19) & 100 & 80 & 100 & 80 \\
\hline Sensitivity (\%) &
\end{tabular}

\section{DISCUSSION}

Brucellosis is a worldwide zoonosis caused by the facultative intracellular members of the bacterial genus Brucella of which at least six species are now recognized these are highly genetically homogenous and the disease is of major socio-economic importance [1]. The present study was planned to study the pattern of the brucellosis in Menoufyia governorate. In the present study we found that, human brucellosis affects all age groups as shown in table (1) this agree with Cetinkayal et al. [7] who found that human brucellosis affects all age groups. In this study we found that, the highest number of cases was found between 15-45 years old (98 cases,
$65.3 \%$ ), this reflects the magnitude of the socioeconomic impact of brucellosis in this area, as it affects mainly the most productive group in the community. This agree with Mantur et al. [8] who found that, 29 cases $(19.4 \%)$ in the age group of $>45$ years old but the least number of cases, 23 cases $(15.3 \%)$ was recorded in the age group of $<15$ years including 1 case $(5.3 \%)$ of chronic brucellosis. Statistical analysis revealed no significant differences among the three groups with respect to frequencies of disease among different age groups as shown in table (1). We found also that, the highest number of cases was found among males (101 cases, $67.3 \%$ ), followed by females (49 cases, $32.7 \%$ ) as shown in table (1). This result is in agreement 
with Jama'ayah et al. [9] who found that, males are commonly affected by brucellosis and Minas et al. [10] who reported that, males were affected more often by brucellosis due to their profession than females. This result disagrees with Hussein and his colleagues [11] who reported higher incidence among females. Probably this discrepancy is related to cultural and epidemiological factors as in developing countries females are in contact with domestic animals. In our study we found that, the highest number of cases was found among residents of rural areas (126 cases, 84\%) while the least number of cases was found among residents of urban areas (24 cases, 12\%) as shown in table (2). This result is in agreement with Kassiri et al. [12] who concluded that, the higher prevalence in rural areas may be due to close contact of individuals with livestock. The number of cases was low in urban areas because all commercialized dairy products are produced from pasteurized milk [10]. We also found that, all of chronic cases came from rural areas. This is probably due to the delay in visiting physician by shepherds and farmers [10]. The main presenting symptoms were as follows : fever $(89.3 \%)$, fatigue $(86 \%)$, chills $(82 \%)$, profuse sweating $(74.7 \%)$, bodyaches $(72.7 \%)$, arthralgia (68.7\%), back pain (65.3\%), appetite loss (62.7\%), headache $(58.7 \%)$, abdominal pain $(46 \%)$, weight loss (44.7\%), nausea and vomiting (40\%) and palpitations (30\%) as shown in table (3). These findings are in agreement with the results obtained by John et al. [13] and Shen [14]. The commonest signs of brucellosis were splenomegaly (43.3\%), lymphadenopathy (38.7\%), hepatomegaly $(38.7 \%)$ and pallor $(32.7 \%)$ as shown in table (4). This result was explained by Alişkan [15] who reported that, these findings are due to the relatively high concentration of brucella in reticuloendothelial system. These findings are in agreement with the results obtained by Hadda et al. [16]. Positive titer $\geq 1 / 1280$ was highly significant more frequent in acute and subacute stages of brucellosis than in chronic stage and control group. Positive titer $1 / 640$ was significantly more frequent in patients groups at different stages of disease than in control group. Positive titer $1 / 320$ was significantly more frequent in subacute and chronic stages than in acute stage and control group. Positive titer $1 / 160$ was significantly more frequent in chronic stage than in acute, subacute stages and control group. Negative serology and positive titer $<1 / 160$ were significantly more frequent in control group than patients groups at different stages of disease as shown in table (5). Mantur et al. [8] concluded that, STAT titer $\geq 1 / 160$ do not signify active infection especially in brucella endemic areas because in areas of endemicity as a high proportion of the population has antibodies against brucellosis. Sisirak and Hukić [24] reported that, in countries where the disease is highly endemic, a large proportion of the population may have persistent $\mathrm{Br}$. specific IgG antibodies, hence under such conditions, the detection of specific IgM antibodies is important to diagnose brucellosis in early phase. The present data revealed that isolation of brucella in blood culture was found in 32 cases $(36 \%)$ in acute brucellosis, 15 cases $(36 \%)$ in subacute brucellosis and 1 case (5.3\%) with chronic brucellosis as shown in table (6). The explanation for the low yield of conventional culture in the present study, appears to be related more to the low number of pathogens in the blood sample and use of different antibiotic treatments for various diagnostic suspicion in other clinical sectors before referring the patients to infectious disease unites than to the technical difficulty of isolation of brucella species from clinical samples. Also bacteraemia in brucellosis may be periodically present and this agrees with Pappas and Papadimitriou [17].

ELISA IgM test was positive in all patients with subacute brucellosis $(100 \%)$, most patients with acute brucellosis $(96 \%)$, most patients with chronic brucellosis (64\%) and negative in all persons in the control group as shown in table (7) and ELISA IgG test was positive in most patients with brucellosis whatever the duration of disease and negative in most persons in the control group as shown in table (8) This result agree with Maha et al. [18] who found that, the examined cases using ELISA of clinically suspected brucellosis yielded positive result with ELISA, (80\%) were positive for brucella IgM while, (64.6\%) were positive for brucella IgG. ELISA IgM was highly specific (100\%) in all groups and sensitive (96\%) in acute brucellosis, (100\%) in subacute brucellosis and (64\%) in chronic brucellosis. While, ELISA IgG specificity in all groups $(80 \%)$ and the sensitivity in acute brucellosis was $(88 \%)$, in subacute and chronic brucellosis was $(100 \%)$. A comparative study conducted by Araj et al. [19] it was argued that, the ELISA method should be preferred because in chronic and complicated cases, STAT and Rose Bengal tests might miss a serious portion of positive cases, 
they reported high sensitivities for ELISA tests of $91 \%$ and $100 \%$ for IgG ELISA and IgM ELISA, respectively. This result was not similar to that of Sanaei Dashti et al. [20] who found that, there are some contradictory reports regarding the diagnostic ability of ELISA in acute brucellosis. Therefore, it is reasonable to further evaluate and standardize the test according to the various geographical regions and populations. ELISA IgM is highly specific $(100 \%)$ in all patient groups and sensitivity is $(95.5 \%)$ in acute brucellosis, (100\%) in subacute brucellosis and (64\%) in chronic brucellosis. ELISA IgG is highly sensitive (100\%) in subacute and chronic brucellosis and (87.6\%) sensitive in acute brucellosis. ELISA IgG specificity is (80\%) in all patient groups. Blood culture is specific in all groups (100\%) but with very low sensitivity $(36 \%)$ in acute brucellosis, $(36 \%)$ in subacute brucellosis and $(10.5 \%)$ in chronic brucellosis. STAT is sensitive in all patient groups $(88 \%)$ in acute brucellosis, (92\%) in subacute brucellosis and $(92 \%)$ in chronic brucellosis. While its specificity is $(80 \%)$ in all patient groups as shown in table (9).

\section{CONCLUSION}

From this study we can conclude that diagnosis of human brucellosis regardless of the duration or focalization of the disease based not only on positive history of exposure to infection and compatible clinical picture but also on laboratory diagnosis. The conventional blood culture for the diagnosis of human brucellosis is time consuming and poses low sensitivity especially with prolonged durations of the disease and in the presence of focal forms but important in species identification. The ELISA method has higher positivity, higher titers and the advantage of identifying different classes of antibodies in comparison to other agglutination methods. ELISA method should be preferred because in chronic and complicated cases, STAT and Rose bengal tests might miss a serious portion of positive cases. Detection of $\operatorname{IgG}$ and $\operatorname{IgM}$ is suggestive of subacute brucellosis while detection of $\operatorname{IgG}$ or $\operatorname{IgM}$ is suggestive for diagnosis of chronic or acute brucellosis respectively. The prevalence of brucellosis is more frequent in spring and summer than autumn and winter.

\section{Funding: None.}

Conflicts of interest: None.

Ethical approval: Approved.

\section{REFERENCES}

1. Tharwat M, Amir H, Abd-Elrahman. Evaluation of a rapid immunochromatographic test for detection of brucella abortus ntibodies in egyptian cattle sera and milk. Alexandria Journal of Veterinary Sciences. 2014, 40:24-28.

2. Afifi S., Earhart K., Azab M., Youssef F., El Sakka H., Wasfy M. Hospital-based surveillance for acute febrile illness in Egypt. A focus on community-acquired blood stream infections. AmJ Trop Med Hyg. 2005, 73(2):392-9.

3. Samaha H., Mohamed T., Khoudair R., Ashour H. Serodiagnosis of brucellosis in cattle and humans in Egypt. Immunobiology. 2009, 214(3):223-6.

4. Mutnal M., Purwar S., Metgud S., Nagmoti M., Patil C. PCR confirmation of cutaneous manifestations due to brucella melitensis. $J$ Med Microbiol. 2007, 56 (2):283-5.

5. Ertek M., Yazgi H., Zkurt Z., Ayyildiz A, parlak M. Comparison of the diagnostic value of the standard tube agglutination test and the ELISA IgG and IgM in patients with brucellosis .Turk $J$ Med Sci. 2006, 36 (3): 159-163.

6. Jain R, Tilak V. Evaluation of different serological techniques in laboratory diagnosis of brucellosis. J Indian Med Assoc. 2008, 106(8):520, 522, 524.

7. Cetinkaya1 Z., Aktepe1 OC. , Ciftci1 IH. , Demirel R. Seroprevalence of human brucellosis in a rural area of Western Anatolia, Turkey. $J$ Health Popul Nutr.2005, 23(2):137-141.

8. Mantur B., Biradar M., Bidri R., Mulimani M., Kariholu P , Mangalgi S. Protean clinical manifestations and diagnostic challenges of human brucellosis in adults: 16 years' experience in an endemic area. J Med Microbiol.2006, 55 : 897-903.

9. Jama'ayah M., Heu J., Norazah A. Seroprevalance of brucellosis among suspected cases in Malaysia. Malaysian Journal of Pathology. 2011, 33(1) : 31 - 34.

10. Minas M., Minas A., Gourgulianis K., Stournara A. Epidemiological and clinical aspects of human brucellosis in Central Greece. Jpn J Infect Dis. 2007, 60(6):362-6.

11. Hussein A., Sayed A., El Feki M. Seroepidemiological study on human brucellosis in Assiut governorate. The Egyptian Journal of Immunology. 2005, Vol. 12 (1), 49-56.

12. Kassiri H., Amani H., Lotfi M. Epidemiological, laboratory, diagnostic and public health aspects of human brucellosis in western Iran. Asian Pac J Trop Biomed. 2013, 3(8):589-594.

13. John K., Fitzpatrick J., French N., Kazwala R., Kambarage D., Mfinanga GS., et al. Quantifying risk factors for human brucellosis in rural Northern Tanzania. PLoS ONE 5 2010, (4): 9968. 
14. Shen M W. Diagnostic and therapeutic challenges of childhood brucellosis in a nonendemic country. Pediatrics. 2008, 121 (5): 1178-1183.

15. Alişkan $H$. The value of culture and serological methods in the diagnosis of human brucellosis. Microbiology. 2008, 42(1):185-95.

16. Hadda V., Khilnani G., Kedia S. Brucellosis presenting as pyrexia of unknown origin in an international traveller: a case report.Cases J. 2009, 1;2:7969.

17. Pappas G., Papadimitriou P. Challenges in brucella bacteraemia. Int J Antimicrob Agents. 2007, 30 Suppl 1:S29-31.

18. Maha A., Abo-Shadi1 A., Alhanouf H., Elmahi M. Serum Levels of Interferon Gamma in Patients with Brucellosis in a Saudi Hospital .British Microbiology Research Journal. 2014, 4(3): 293-305.
19. Araj G., Kattar M., Fattouh L., Bajakian K., Kobeissi S. Evaluation of The brucella immunglobulin $\mathrm{G}$ and IgM enzyme-linked immunosorbent assays for diagnosis of human brucellosis. Clin Diagn Lab Immunol. 2005, 12:1334-1335.

20. Sanaei Dashti A, Karimi A, Javad V, Shiva F, Fallah F, Alaei MR, et al. ELISA Cut-off Point for the Diagnosis of Human Brucellosis; a Comparison with Serum Agglutination Test. Iran J Med Sci. 2012 ;37(1):9-14.

Peer reviewer: Tarik Zaher ,Professor of Tropical Medicine and Hepatogastroenterology, Faculty of Medicine, Zagazig University, Egypt. Mohamed I Radwan, Assistant Professor of Tropical Medicine and Hepatogastroenterology, Faculty of Medicine, Zagazig University, Egypt.

Editor: Mohamed Emara, Lecturer of Tropical Medicine and Hepatogastroenterology, Faculty of Medicine, Zagazig University, Egypt 